\title{
The Impact of the Hotel Industry on the Competi- tiveness of Tourism Destinations in Hungary
}

\author{
- Albert Tóth Attila
}

\begin{abstract}
This paper focuses on a complex question from the perspective of the hotel industry. It tries to draw attention to the importance of hotels, enhancing it on the basis of the tourism destination competitiveness models and introducing the role and place of the hotel industry in the most important models.

The hotel industry research evaluates the most important tourism destinations of Hungary on the micro-regional level that justifies the importance and contribution of the hotels and accommodations to competitiveness and success of tourism destinations with exact results. As a result of the research, the micro-regional destinations can be ranged within three groups in Hungary. In the first group of the most developed and most competitive tourism destinations, the hotel industry plays a very important role. In these regions, the hotel industry has a significant effect not only on competitiveness of tourism but also on general development of the regions. In the second group, which can be still called tourism destination, tourism and the hotel industry both play a significant role, but only the competitiveness of tourism can be considered good, the effects of the tourism on general development of the region can be proved only to a lesser extent. In the third group, the effects of tourism and the hotel industry can only be experienced to a lesser extent. The majority of these regions are not considered to be attractive tourism destinations for tourists any more.
\end{abstract}

Keywords: hotel industry, tourism destination, competitiveness, Hungary

JEL Classification: $L 83$

\section{INTRODUCTION}

Hotels and the hotel industry belong to the most important super structural elements of a tourism destination, without these, no destination could be competitive. Tourism destinations would not have any upholding power without hotels and high quality hotels, tourists would travel through them or they would mean a place to visit for a one-day trip only, with significantly lower incomes and less possibility of work for the regular residents.

The different phases of development of a tourism receiver area show a very close connection to the capacity of hotels, accommodations, tourist traffic of the hotels and the most important tourist traffic and utilisation indexes.

From the increase in capacity (the number of hotels and rooms), the investors' willingness cuts a fine figure if the international investors also appear beside the small and medium-sized local enterprises. Foreign investors entering the market represent a significant advance in the life cycle of destinations too, because the chains of hotels are only interested in the development through 
establishment of small or big hotels of high quality if they can plan in the long run and if they consider the destination to be a promising and competitive tourism receiver area.

\section{THEORETICAL SOLUTIONS}

Many people have already dealt with tourism, the hotel industry and tourism destinations in the international tourism special literature. The most important authors who have been dealing with accommodation and the hotel industry too are discussed below. These authors introduced the importance and significance of accommodation, the hotel industry within the system of tourism.

In the volume of essays and studies of Clarke (2010) relating to Hungary, thirty essays have dealt with the Hungarian coherence system of tourism competitiveness, some of them with the hotel relations separately too. Priszinger \& Clarke (2010) analyse the risk factors of development of the Hungarian wellness hotels, Gyurácz-Németh (2010) assess the innovation possibilities of the hotel management. The authors mentioned above give an overall picture of characteristics of the hotel industry, the connection between the attracting forces and tourism destinations in the books, within the system. The essays try to reveal the relations focusing on particular subfields.

\subsection{Competitiveness of Tourism Destinations}

Each tourism destination, just like the products themselves, has a specific life cycle curve, which depends on geographical location, the size, the attraction forces, the tourism products, the loadbearing capacity and the development level of a territory very much.

The Tourism Areas Life Cycle Model of Butler (1980) follows the stages of development of evolution of a destination. It means that it is not a model of competitiveness but it can be an excellent starting-point of the evaluation of competitiveness of a destination, if we know and access it. The sequence of the most important stages, exploration, involvement, development, consolidation, stagnation, decline or rejuvenation and the assessment in which stage the destination can be found right now, is very important from the perspective of competitiveness too.

Different stages of the life cycle of tourism areas show a very close connection with the capacity of hotels, accommodations, tourist traffic and the most important index numbers of the accommodations.

The research is based on this mainly, with assessment of the hotel capacities, the available rooms, the growth of overnight stays and number of guests and the most important index numbers of the hotel industry.

A destination can only be competitive and successful when there are accommodations, hotels of suitable number and capacity of the area (critical range of elements of capacity), that can support increase in guest numbers, their accommodation and stay for a longer time, hereby higher spending, which means work places, investments, tax incomes in a particular destination.

The model developed by Ritchie \& Crouch (2003) is the most comprehensively and circumstantially elaborated model for competitiveness of tourism destinations. The two authors have already dealt with the subject in the early 90 s and they introduced the first model at the 43rd con- 
gress of AIEST (Association Internationale d'Expert Scientifique du Tourism: International Association of Tourism Experts) in 1993, which they have continuously developed during the years. The fully developed version of the model appeared in 2003, which was published in a book. According to the model, the competitiveness of a tourism destination is basically determined by five main groups of subjects, which are still influenced by further external environmental factors too. The basic factors and resources mean the starting point that the further factors are built on. They have already been important from the point of view that one can decide whether the tourism destination is suitable for tourism development or not. The following factors belong here: state of the infrastructural resources, accessibility, human and financial resources, hospitality, tourism service providers, local political intention and support for the development of tourism. After the model, the central resources and attractive forces are built on the following factors: climate, flora and fauna, landscape, culture, history, events, programmes, entertainment facilities, religion, ethnic roots, etc., and the tourism superstructure, including the accommodations, hotels, hospitality, theme parks, etc.

From the view point of the competitiveness and success of a destination, the next level is about the destination management which plays a particular role. The main components belong to the scope of duties of tourism management; it means that they touch upon professional questions. They are as follows: marketing duties, organisations, service level, quality of the services, pieces of information, research.

The qualifying and strengthening factors belong to the following level, such as location, safety, and price level of the destination, interdependence, image, and capacities. All of them are influenced by the global macro and micro environments and the relative advantageous features of the destination and its competitive improvable resources.

The later and even more improved model of Ritchie \& Crouch (2005) may describe the competitiveness of a destination most fully; it determines various territorial units to the examination possibility of a destination too. According to the two authors above, one can examine the competitiveness of a tourism destination at different levels: the level of macro regions, including several countries. According to UNWTO statistics, big tourism regions can be an example for this. However, within Europe, different countries can be grouped together from the point of view of tourism, for example the Mediterranean, the Scandinavian countries, the ski regions in the Alps. On a national level, that is advantageous from the perspective of the analysis because beside the national tourism statistics, the availability of other social, economic index-numbers can make the analysis easier too, as compared with other kinds of regional units where no wider ranging data is available.

An example of this would be data relating to a specific territory within a country, a large region or a comprehensive regional administrative unit. Other examples could be small and mediumsized regions within the country, for example in Europe these are planning-statistical regions (NUTS-2 level) or tourism regions or smaller regional units too. In Hungary these would be different counties and holiday regions (also called micro regions).

The models of Porter $(1980,1990)$ are the most well-known, because of their wide applicability. The earlier model of 1980 is dealing with a general strategy of competition. Two important ele- 
ments of advantages of competitiveness are the scope of expenses and differentiation, distinctness. The Porter model of 1990 consists of five main components: first, competition still existing on the market, in case of a destination, the competition of the service providers of particular receiver areas, possible excessive hotel capacities, non-storability of the tourism products on the supply side, in this way, their damageability. The further four components are analysing demand and supply competition position of the destination, bargain position of the customers-suppliers, risks and danger situation caused by the newcomers and the replaceability of the destination. A tourism destination can be easily replaced by another destination with similar features by the tourists, but in the same way an investor can also choose another location for tourism investments of any kind in case of a hotel, theme park, restaurant and other projects.

It is also possible to describe and analyse the destination and the positions of the competitors in the hotel industry with the Porter model.

Poon (1993) accepts the model of Porter, but he is also criticizing it after which it can be used in production rather than in the service sector. Therefore, he worked out two model types too, one for the purposes of industrial production, while the other one for tourism destinations. In the destination model of Poon, the main emphasis is laid on the role of innovation and the quality in the destination model but he also considers important that tourism becomes a leading sector in the destination. Environmental elements, sustainability and strengthening of the service providing sector are important elements of successful destination strategy. Development and appearance of the tourism products that have not been present in the destination yet also constitute an important part of the strategy model.

The elaboration of the Price Competitiveness Model is linked with the name of Dwyer, Forsyth \& Romao (2000). Prices are the main components of the model that are compared on purchasing power parity in case of different, international tourism destinations, primarily in case of countries. Those tourism expenditures get into the tourism consumer basket, with which one has to calculate in case of every single international travel, just like air-ticket, price of hotel room, transfer costs, boarding costs, price of admission tickets, etc. Constant change in the courses and prices as well as the collection of suitable data mean some difficulties as far as the exact and upto-date usability of the model is concerned, however, it provides a good basis for comparison in a particular moment of examination. A further problem is the varying levels of hotels and other services in different countries, which can even occur in different regions and cities of the same country as well. The prices of services can also differ significantly in various countries; there are some which are very cheap in a particular country and in the other one very expensive and vice versa. In case of greater travel distances, higher travel costs can distort the index, therefore in order to cut the effects of distortions the competitiveness index is given in three components. The fist one is the index of travel costs, the second one is the index of services used in the destination, while the third one introduces the former two indexes together in total. The advantages and disadvantages of the model are really the same because they narrow down the tourism competitiveness of a destination to comparison of the prices and the courses but it shows the affordable destinations for the tourists in a very clear way with the assistance of comparisons. Many tourists carry out a model analysis of a very simplified and comparative character before their travel, but this version based on more serious calculations is also applied by travel agencies 
and tourism organizations when they publish how much one euro or dollar tourism service is worth considering the price level of a particular country or how much it costs in comparison to the price level of their own country.

Dwyer worked out a new model with another co-author in 2004, which differs from the former price-competitiveness model (Dwyer \& Kim (2004). The model uses the content elements of the Ritchie-Crouch model too, but it is different in two respects. Firstly, using the experience of the former price-competitiveness model, it includes the demand conditions that depend on the supply prices. The other one is connected to it, the dominant elements of social-economic welfare and quality of life which also influence the competitiveness.

The TTC Index (Travel and Tourism Competitiveness Index) was published by the World Economic Forum on the basis of the Travel \& Tourism Competitiveness Report in 2007 for the first time. As part of the preparation, a number of organizations, i.e. UNWTO, WTTC and the IATA (International Air Transport Association) took part in the assessment of 124 countries. Its direct antecedent was the Competitiveness Monitor which was worked out by the WTTC to measure competitiveness with the assessment of 23 variables.

The TTCI global index shows the order of countries according to their tourism competitiveness. The former versions still consisted of 3 sub-indexes but the recent modified TTC Index (2015) have already been composed of 4 sub-indexes, which include 14 pillars and examined the components based on the main scope of subjects.

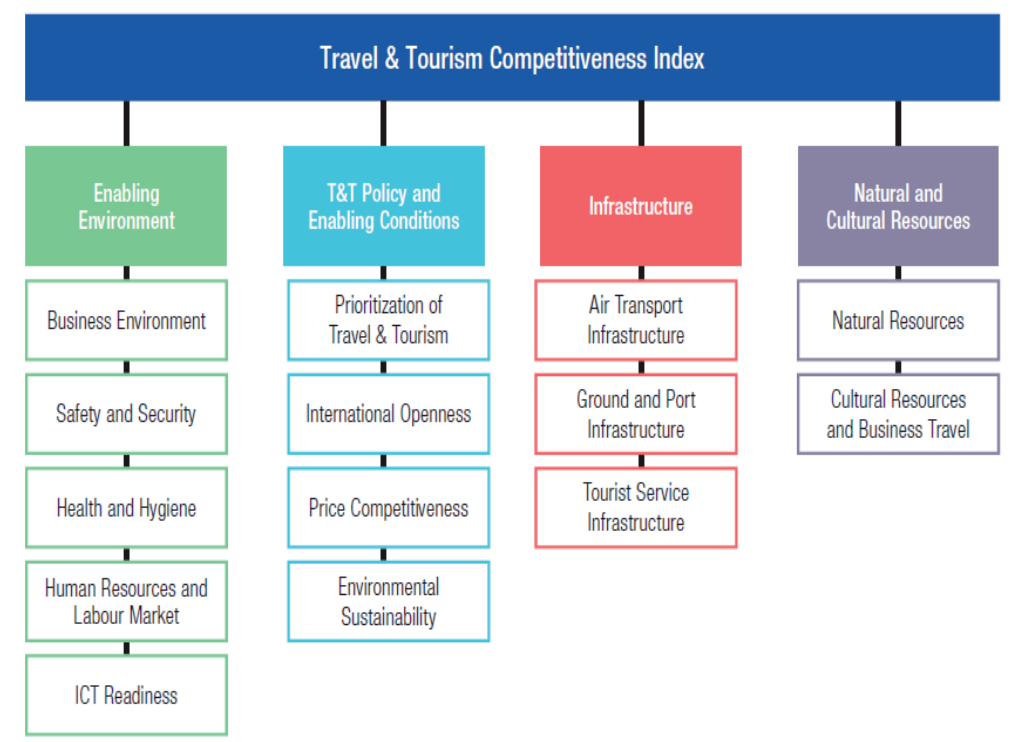

Fig. 1 - The structure of the latest (2015) Travel and Tourism Competitiveness Index Source: WEF Travel and Tourism Competitiveness Index 2015 
Blanke \& Chiesa (2009) say that the TTC Index has several weak and criticisable points:

the sub-indexes are included in the global index with the same emphasis which has been the bone of contention right from the beginning. It is favourable for some countries but for others, it is not. For example, it is clear that it is less complicated to modify the environment of regulations, make it competitive without investments too rather than change the elements of the infrastructure or the resources available.

The TTC Index shows the tourism competitiveness of individual countries while the tourism destinations do not cover the whole territory of the countries. While regulations usually refer to the whole country, with the exception of some federal, provincial, self-governing, etc. regulations, all of other important tourism indexes are only valid for the tourism destinations.

According to Vanhove (2011), the TTC Index can be considered static, as if it was a snap shot of the tourism competitiveness of the country, while the competitiveness models and their key factors can be considered dynamic, thanks to the effects of planning, innovation, destination management, quality management, etc.

The newest TTC Index of 2015 has already been assessing 141 countries and the methods were changed too. Instead of the former 79 indexes, they examine 90 indexes. Two-thirds of these are the measurement of statistical data, one-third is „Executive opinion survey”.

From the assessed countries, economically and from the point of view of tourism, developed countries are on the top of the list in global order: 1. Spain (Value 5.31), 2. France (5.24), 3. Germany (5.12), 4. USA (5.12), 5. United Kingdom (5.12). From the V4 countries the order runs as follows: 37. Czech Republic (Value 4.22), 41. Hungary (4.14), 47. Poland (4.08) 61. Slovak Republic (3.84).

From the common profile picture of Hungary and Europe and Caucasus, one can see that among the 141 countries, Hungary and Europe are strong at the themes of Health and Hygiene, Safety and Security, Tourist Service.

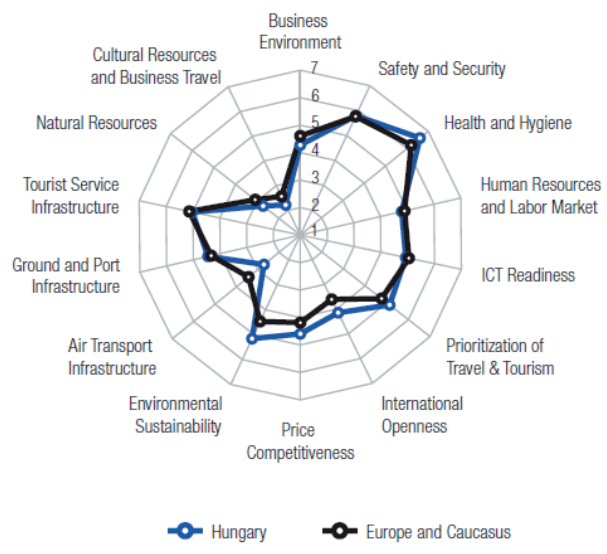

Fig.2 WEF TTCI Country Profile of Hungary The performance on the single indicators composing each pillar (1 to 7 scale, $1=$ worst score, 7 = best score) Source: WEF TTCI 2015 (p.174) 
The hotels belong to pillar 12, within that to the "Tourist Service Infrastructure” and within this the index 12.01 measures the hotels, the order of number of hotel rooms in relation to 100 people. „The availability of sufficient quality accommodation, resorts and entertainment facilities can represent a significant competitive advantage for a country. We measure the level of tourism service infrastructure through the number of "upper-level" hotel rooms complemented by the extent of access to services such as car rentals and ATMs." (WEF TTCI, 2015)

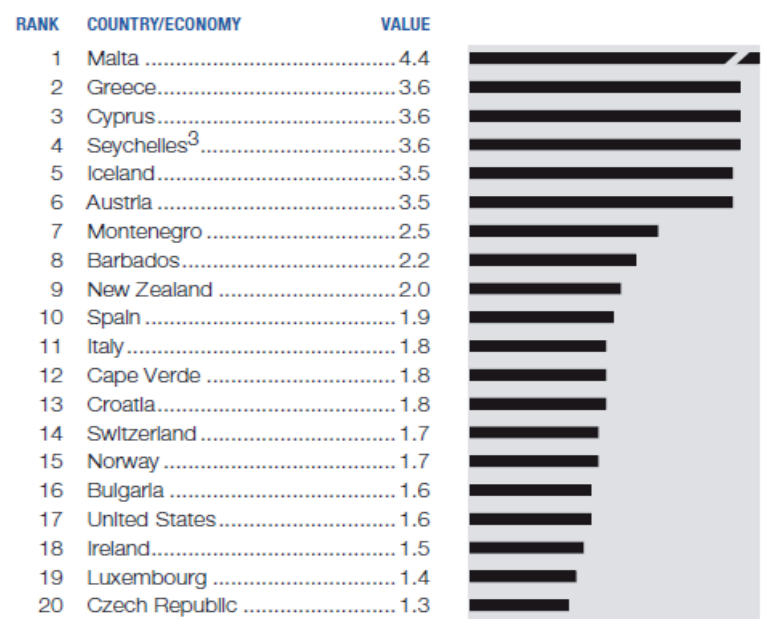

Fig.3 WEF TTCI, 12. Pilar - Tourist Service Infrastructure 12.01 Hotel Rooms Source: WEF TTCI 2005 (p. 466)

Malta with a low number of inhabitants is leading order of the countries in this category as far as the relative hotel capacity is concerned, but one can see that numerous small or medium-sized European countries also take a prominent place in the rank order. Spain, Italy and the USA can be found in the prominent places of the list too, in spite of their high number of constant inhabitants. This also proves the tourism reception capacity of these countries. In the order of hotels, the Czech Republic from the V4 countries got into the TOP 20, from the other V4 countries Hungary takes the 45th (Value 0.7), the Slovak Republic (Value 0.7) the 46th and Poland (Value $0.3)$ the 75 th place.

\subsection{Key elements of the models in practice}

The applicability of the competitiveness models differs from the regional delineations. Not each model is suitable for the assessment of small and big regional units and the approach methods of the examinations are significantly different from each other. However, one can also detect some overlap between several models and that the later models usually build on experience of the former ones too.

From the synthesis of the models, it is necessary to emphasize the most important common key elements (Vanhove, 2011), because every region can have specialities but not every model can be used for every region, so their use in practice can also be different. 
Without any of the natural, man-made or cultural attractions, one could hardly imagine a successful tourism destination. The synergy effect of attractions can strengthen the attraction. This means that, if one can also find several attractions in a destination, the global attraction can be the multiple too (Puczkó \& Rátz, 2000). The cultural elements are also included, so the hotel industry as well, which does not definitely mean any attraction on their own but they are absolutely necessary to the settlement of tourism. Some special or unique hotel types, which can provide special adventure or services, can already be attractions on their own, if the selection of a hotel means the main motivation. So, when choosing a hotel, the selection of the destination also happens, even though tourists choose the destination at first.

The incomes of the tourist traffic are generated by tourism, a general price level of the particular receiving area and in case of international tourism, and the rate of exchange of the sending and receiving country. An overestimated exchange rate of the receiving area makes the travel more expensive, an underestimated one can support, encourage it. Taxes also influence the prices, tourists can directly feel it through the value added tax, the sectoral taxes and the local taxes too.

At present, Hungary is a record holder within the European Union with $27 \%$ VAT, which is valid in the tourism-hospitality branch too, with the exception of its accommodation service where the advantageous tax rate of $18 \%$ is in force. The VAT tax rate of the accommodation tax rate is significantly higher than the average of $10 \%$ in the European Union, which makes the competitiveness of Hungarian accommodation service providers much worse on the international market.

After the standpoint of the HOTREC (2002), considering the fact that the VAT tax rates influence the competitiveness of the branch directly, the possible lowest VAT tax rate should be used for the hotel and catering services.

Innovation has two types of interpretation in the case of a destination. On the one hand, how quickly the results of the technical-technological innovations appear in the particular receiving area and how quickly the tourists can use and apply them. That can be a series of cultural programmes in the attraction sector but even a new theme park or the opening of a new hotel in the accommodation sector, which can also mean a new clientele for the destination. (Kovács, 2004).

The strategic planning is a must for each tourism destination, which means on the one hand, the regional development strategy in the medium and long run, on the other hand, the marketing strategy too.

The plans usually use internal and external situational analyses, competition analysis, and forecasts. They draw up the mission, determine the market segments, the target groups, the market position, the strategy and the plan of actions how to reach them. Beside a continuous control, if needed, they modify the plans and the targets to be reached (Kozma, 2006).

Positioning of a tourism destination is a more complicated and lengthier process than the usual segmentation of products, determination of the target markets and the market positioning. The most important elements of positioning of a destination are evolvement of the advantageous image, its maintenance, its distinctness from other destinations and its introduction to the potential 
tourists. One best example for the branding of a tourism destination is St. Moritz in Switzerland, where the brand policy that had been used consistently over long years produced the expected results and it became well-known all over the world. (Ferner, 1994).

According to Piskóti (2012), the 'branding of the areas, regions is not a one-time, clear duty but the building of a - often complicated - brand system is needed. Building of a brand is especially important in the field of tourism.' He found a coherent system of elements of the regional tourism brand system and described a possible version of the main steps of the brand's building. (Piskóti, 2012).

For the successful operation of a tourism destination, it is necessary that professional organizations, tourism clusters, local governments, educational institutions, chambers and the enterprises cooperate on a suitable level, even if, especially in the case of enterprises, it is about counterincentives and they are competitors of each other too. The development of the TDM (Tourism Destination Management) system in Hungary based on international samples is essentially about this and 'its target is the establishment of the system of a sustainable and competitive system of tourism and its operation in the region receiving tourists.' (Lengyel M., 2008).

Buhalis (2000) considers the marketing role of a destination very important, like Tsai, Song \& Wong (2009), beside several factors, they emphasize the role of marketing and human capital, and both in case of the destinations and the competitiveness of the hotel industry, in case of the hotels, the educational level and the role of training are of high importance too. The principle to develop tourism to a leading branch in the destination (Poon, 1993), (Vanhove, 2011) is both a target and it is very important for a successful and competitive receiving area too. Quality management and quality approach will be essential for each tourism enterprise, the number of high quality services provide the perceptible quality for the tourists in a destination. In addition to company and other general quality management systems, the legal regulations and the observation of the ethical norms and their making observed by the authorities are also very important (Code of Conduct, Code of Practice), which can be achieved through regular controls. Most of the qualifying systems that are used in the field of tourism (Hotelstars Union, TÜV Rheinland, ISO, EHQ, Leed, Green Hotel, etc.) serve the same target directly or indirectly. We can also make a detailed analysis of the hotel industry if we have the suitable hotel data, on the basis of which one can count the kind of indexes (Fair share, Market share, Market Penetration Index, Average Rate Index, Revenue Generation Index) that can be used in practice too in order to assess tourism and the hotel industry, if we want to compare and assess two or more destinations on the basis of exact data, in the sphere of competitors. (Géher, 2000) Sustainability in the hotel industry is becoming increasingly important too. More than a hundred hotels won the title of Green Hotel in Hungary in the past twenty years, the majority of these hotels can be found in the regions that are developed from the point of view of tourism which can also contribute to the improvement of the competitiveness in the particular destinations. Besides environmental sustainability, economic sustainability is also important and the accommodation sector has to apply the current sustainability measures too for the sake of economic development (Jurigová, Tučková \& Kuncová 2016).

The measurement of the GDP on regional level and the comparison of the most important indicators of tourism, including the hotel industry, are commonly used in Hungary too, on the basis of the indicators of the HCSO. The monitoring system for destinations that is recommended by 
Jurigová \& Lencsésová (2015) and the environmental, economic and social indicators that are also included can be applied to the tourism destinations in Hungary too. I also applied similar indicators that are measured and published by the Hungarian Central Statistical Office during my primary research. According to the results of the research of Vaškó \& Abrhám (2015), most visitors search for the accommodations (88 percent) and the destinations (87\%) on the internet. Currently internet platforms can already influence the marketability and the success of the tourism destinations, within this that of the hotels to a significant extent and they also affect the competitiveness. The investments of companies which apply innovative (Olaniyi \& Reidolf 2015) and sustainable eco-system technologies in rural areas can also contribute to the development and competitiveness of the tourism destinations (Laužikas, Tindale, Bilota, \& Bielousovaité 2015). There are examples for this in Hungary too. The success of some new rural eco-hotels can prove that innovation and sustainable solutions are more and more important in the hotel industry. Other organisations, for example the so-called clusters can also contribute to the sustainable development of a destination (Tvaronavičiené, Razminiené \& Piccinetti 2015). The biggest and most important tourism cluster in Hungary is the Pannon Thermal Cluster that is gathering the thermal baths of the western part of the country. These baths are in close connection with the hotels because the biggest hotel capacities and the hotels of the highest quality can be found operating next to them.

\section{OBJECTIVES AND METHODOLOGY}

The main objective of the paper is to investigate the impact of the hotel industry on the competitiveness of Hungary's tourism regions. The paper is a part of research that aims to analyse regional and qualitative structure, competitiveness of Hungarian hotel industry and its contribution to the development of a particular destination. The literature review deals with assessment of the most important models relating to competitiveness of the destinations of the hotel industry and tourism. The target of the study of the destination competitiveness models was to reveal the role of the hotels in the models which mostly consider the role of the hotels, the accommodations as part of the infrastructure. The role of the hotels is highly significant because the main part of the incomes from tourism is realised by the enterprises in the tourism destinations.

The empiric research analyses Hungarian hotel industry on the level of micro regions, on the basis of economic and social indexes, tourism and hotel index-numbers. I examined and introduced the relationship between them with SPSS research and data analysis. The research span from 2007 until 2015 and it was performed with collection and analysis of the economic, social, regional and data on tourism and within this detailed hotel data that originate from the database of $\mathrm{KSH}$.

The SPSS research touched upon more than thirty types of economic and social index-numbers (e.g. PIT per capita, number of enterprises per one thousand inhabitants, the proportion of job hunters within the total population, proportion of the pensioners, housing stock per one thousand people, the number of cars per one thousand inhabitants, the number of family doctors per one thousand people, the number of students per one thousand inhabitants, number of family doctors, etc.) and more than 15 types of indexes of tourism, hotel industry (e.g. number of guests, 
overnight stays, accommodations, hotels, capacity, occupation indexes, average price, RevPar, incomes, etc.) for all micro regions and in every year. I collected and grouped the data from the database of $\mathrm{HCSO}(\mathrm{KSH})$ and then, I prepared them for the data input and the assessment.

The research encountered numerous objective difficulties, including the fact that a lot of legal rules have changed influencing the possibility of future comparison of the statistical data. The number of micro regions, later districts, has changed during the assessment period in Hungary, therefore, this also caused difficulties in following the changes in the input and data processing, and the changes do not, or only at an inessential extent, distort the results.

There were changes in the legal regulations regarding tourism and hotels. The Government Decree 239/2009 (X.20.) on conditions applicable to the provision of accommodation and to issuing licences for operating accommodations was published for example. The Hotelstars Union hotel qualifying system was introduced in Hungary and in numerous countries in Europe, which also influenced the hotel industry and the quality categories of hotels.

As the use of the Hotelstars Union system did not become compulsory and a great number of hotels did not qualify themselves either, a new hotel category appeared in the statistics of HCSO as in the year of 2012: the large number of the non-qualified hotels "without category". For example in the year 2012, the proportion of the non-qualified hotels was more than ten percent, which did not enable the exact follow-up of the hotel categories unfortunately any more.

As part of the research, I conducted 32 structured interviews with experts in this area, who were concerned in one form or another. Among the interviewees, there were hotel owners, hotel leaders, chief executives of tourism professional unions, mayors of cities who are significant from the point of view of tourism, experts dealing with regional developments, leaders of tourism management, educators, researchers who participate in university tourism education, or who cover some areas in tourism education.

\section{RESULTS AND DISCUSSION}

The research of tourism on a regional level has some traditions in Hungary (Aubert, 2007)

(Fehér \& Kóródi 2008), which I have studied as a starting point, but I also extended my research into the detailed index-numbers in connection with the hotel industry, (Occupancy, Average Rate, RevPAR, Revenue, etc.) that have not been used previously because it was not about the research of the hotel industry.

Basically, those micro regions are significant, as far as the hotel supply is concerned, where one can find cities and settlements that are important from the view point of tourism and hotels, and commercial accommodations are also operating. According to the data from 2011, there was no single hotel operated in 38 from the 175 micro regions. This means just a quarter of the micro regions and also the territory of the country. There were just three counties in the country where at least one hotel was operating in each micro region, for example Zala, Csongrád and Tolna, however, in the micro regions on different places of the country, there was really operating only one hotel (HCSO, 2012). 
During the analysis, I aimed to introduce numerical links between the two main groups of variables, the economic and social development levels of the destination and its importance, competitiveness in the hotel industry and tourism.

The level of economic development is in moderately strong connection with the relative indexes of tourism (indexes per 1000 permanent residents). The more developed micro regions have, a bigger capacity for tourism.

One also has to make a difference between the micro regions with significant tourism attraction and those with modest attraction but developed economy when analysing the micro regions. In general, one can state that leisure tourism is typical for those mentioned above and accordingly, the holiday, medical and wellness hotels are dominant from the types of settled hotels in these tourism destinations.

An economically advanced micro region including developed cities, which is an administrative centre too and where industry is developed and one can recognise the presence of logistic centres, a knowledge center, the level of development of the region itself generates tourism, economic activity is necessarily accompanied by the profession-tourism.

In general, different types of the city hotels are operating in these settlements, the business and conference hotels specialised for MICE are of enhanced importance.

One can recognise a group of the micro regions in which the hotel activity is very strong. I have grouped each micro region according to the hotel indexes on the basis of the 2011 data, using the following method: hierarchical cluster analysis with the Ward's method, taking the Euclidean distances for the basis.

In the research, I examined casual links between the data with economic and hotel types first of all, therefore, I examined the difference between the economic performances of the groups generated on the basis of relative hotel indexes with an analysis of variance (ANOVA). Instead of the Pearson's correlations, we applied the analysis of variance in order to confirm the results, making them more sophisticated. The three clusters received the following average points of the economic development factor:

Tab. 1 - Activity and Competitiveness of the Hotel Industry in Hungary by micro-regions Source: results, own research

\begin{tabular}{|l|c|c|c|c|c|c|}
\hline & $\mathrm{N}$ & Mean & Deviation & Std. Deviation & Minimum & Maximum \\
\hline Most active & 8 & 1,1900167 &, 82896993 &, 29308513 &,- 25722 & 2,12174 \\
\hline Active & 15 &, 5474382 &, 79028870 &, 20405166 & $-1,11988$ & 1,70255 \\
\hline Less active & 152 &,- 1166560 &, 97162702 &, 07880936 & $-2,89395$ & 2,04289 \\
\hline Total & 175 &, 000000 & 1,0000000 &, 07559289 & $-2,89395$ & 2,12174 \\
\hline
\end{tabular}

As it can be seen from the above table of the group averages above, there is a significant difference between the levels of economic development of the micro regions that are active from the hotels' point of view. Its tendency confirms positive causal link we received during the correlation calculation. The $\eta^{2}$ (Eta-squared) index gives the strength of relation, which can be calcu- 
lated on the basis of the analysis of variance (ANOVA). In this case, $\eta^{2}=10.18$. It means that our grouping on the basis of the hotel indexes explains the level of development of the micro regions in 10.18 per cent, which is relatively low, but it is a strong explanation power.

Tab. 2 - Activity and Competitiveness of the Hotel Industry in Hungary by micro-regions Source: own research

\begin{tabular}{|l|c|l|}
\hline & N & Names of the micro-regions in Hungary \\
\hline Most Active & 8 & $\begin{array}{l}\text { Hévíz, Csepreg (Bük), Balatonföldvári, Balatonfüredi, Hajdúszobos- } \\
\text { zlói, Sárvári, Siófoki, Zalakarosi micro-regions. }\end{array}$ \\
\hline Active & 15 & $\begin{array}{l}\text { Balatonalmádi, Bélapátfalvai, Budapest, Egri, Fonyódi, Gárdonyi, } \\
\text { Gyulai, Keszthelyi, Mosonmagyaróvári, Siklósi, Sopron-Fertődi, } \\
\text { Sümegi, Szentgotthárdi, Tokaji, Zalaszentgróti micro-regions. }\end{array}$ \\
\hline Less active & 152 & Rest micro-regions of Hungary \\
\hline Total & 175 & All micro-regions of Hungary \\
\hline
\end{tabular}

From the three groups, those micro regions can be found in the first one (Hévíz, Csepreg (Bük), micro regions of Balatonföldvár, Balatonfüred, Hajdúszoboszló, Sárvár, Siófok, Zalakaros) where, as compared with the population, the relative (per 1000 inhabitants) index-numbers are the highest and one can feel close connection with the level of economic-social development and tourism, within this the level of development of the hotel industry and its competitiveness as well.

Apart from the capital, the highest quality-level hotels can be found here, those that produce the best index-numbers (Occupancy, Average Rate, RevPAR, Room revenue, Total revenue). In 2013, for example in Sárvár, the 4* and $5^{*}$ hotels reached the highest average rate in the country as far as their prices are concerned. (HCSO, 2014)

If we did not consider it on the micro region but on the settlement level, 7 settlements from this group are included in the TOP 10 list of Hungary in respect of overnights.

In the second group (micro-regions of Balatonalmádi, Bélapátfalva, Budapest, Eger, Fonyód, Gárdony, Gyula, Keszthely, Mosonmagyaróvár, Siklós, Sopron-Fertőd, Sümeg, Szentgotthárd, Tokaj, Zalaszentgrót), the settlements still have significant tourism and hotel industry, as a result of high number of population, the relative indexes per 1000 inhabitants show a less advantageous picture in comparison to the first group.

Budapest got into this group, which was still treated as a micro region when the analysis was prepared and because of its number of inhabitants (1.7 million inhabitants in 2011) it could not get into the first group. The most important tourism attraction can be found in the settlements belonging to the first two groups in the country, the important locations of the medical tourism, the best medical and amusement baths and the related spa wellness hotels.

Hotels of the top category and the highest income and best index-numbers can be found in the 5 th district of Budapest, along the Danube or next to it, the majority of which belong to big chains of hotels (Four-Season, InterContinental, Marriott, Kempinski, Accor-Sofitel). 
The third group (152 micro-region) became a big summary group, what they share is that on the basis of the relative development level indexes, from the point of view of tourism, they do not belong to the micro regions with favourable indexes any more.

These 152 micro regions can be divided into further 3 sub-groups, from which in the first group, encompassing circa 30 micro regions, tourism is still considered significant.

Large rural cities, types of medical and holiday resorts belong here, where the hotel capacity is lower, but there are still some tourism attractions, including baths, and from the professional tourism (MICE) primarily business tourism is present in these cities. On the basis of the calculated indexes, two large cities were also included, which have more than 100,000 permanent residents, all of them are important industrial, in particular, automotive centres. Thanks to the activity of the Audi factory in Györ, and Mercedes in Kecskemét, business tourism is significant, but because of a high number of inhabitants, relative indexes are not so favourable any more.

The hotel and accommodation capacity is in the third sub-group (about 80 micro regions), already very low, they are rather able to meet requirements of the domestic tourists, the number of foreign overnight stays is already very low.

The forty or so micro regions belong to the third sub-group, where there are not any hotels and tourism is not typical either.

In the horizontal drawn by each main component and the level of economic development of the micro region, the location of each region can be drafted. As Fig. 4 shows, the populous group of the micro regions belongs to the rank with a low tourism reception capacity. We can see on the scatter graphic that both the low and the high level of economic developments can belong to it, e.g. industrial centres or lagging regions. Besides, we can see another group too, the rank of regions with significant tourism reception capacity. It is apparent that a higher level of economic development accompanies a bigger tourism reception capacity. The previous correlation, the analysis of variance indicated these relations.

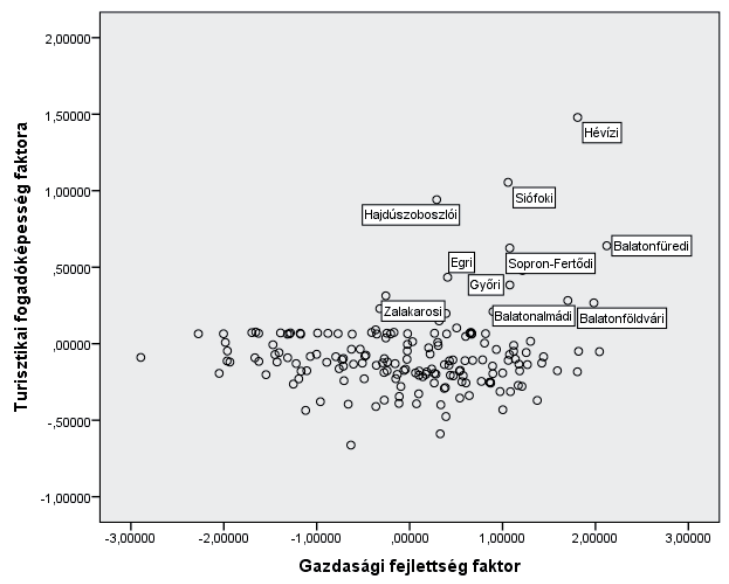

Fig. 4 - Scatter graph. Tourism Capacitability and the Economic Development (Vertical: Tourism C. / Horizontal: Economic D.) Source: own research 
It is also worth analysing how the values of other main components relate to the level of economic development. It reveals that the correlation is stronger because the level of economic development and the tourism capacity utilization and rentability correlate relatively strongly (statistically medium strength) $(\mathrm{r}=0,44)$.

Thus, one can see that the tourism reception capacity itself is in less strong connection (but it can still be shown) with the level of economic development because the tourism attraction is dominant by the developments and capacity extensions, however, the level of economic development and the tourism economic efficiency indexes on the micro region level show a stronger correlation. It means that one can reach a significant REVPAR index in an economically advanced region, or an economical branch of tourism industry can establish the basis of the level of economic development on its own.

The hotel economic efficiency indexes (capacity utilization, room utilization, charge for accommodation per night, REVPAR index, room average price) are significantly different in those micro regions where outstanding, significant and low hotel activity is typical. To prove this, we performed an analysis of variance again, where the level of the growth of capacity was the dependent variable, while the previously formed three micro regional groups which were differently active from the point of view of tourism was the independent variable.

I compared the micro regions that were grouped after the economic-social development indexes and those grouped according to the hotel activity with each other. I used the method of crosstabulation. Those regions which possess tourism with a strong hotel basis must belong to the advanced economic regions. If it succeeds to establish a tourism centre, its economic returns do not fall behind either.

It means that economic development on the micro region level is in connection with the relative economic development of the hotel industry. The higher level of economic development means the higher the level of capacities and income in the hotel industry are, and the higher level of hotel activity is accompanied by a better economic potential.

We had to complete the quantitative assessments by questions and answers to the structured interviews because the numbers did not reveal all correlations either; a qualitative assessment was needed too. The regional concentration of the hotel industry in Hungary was considered as a fact that has developed during decades and it cannot be changed very much for some time either.

There have been contradicting opinions about one important question which related to the focus of improvement of the hotel industry, whether it was the contribution to improvement of the underdeveloped regions or to further development of the already more advanced regions.

This was the question, to which we received the most different answers and there were extremely polarized opinions too.

'Improvement can contribute to development of tourism in undeveloped regions better. Creation of new jobs, through suppliers can contribute to development of economy too.'

It was also submitted that tourism and the hotel industry really contribute to further development of the developed areas; however, they do not equalize but rather increase the differences between the developed and the less developed regions. 
One mayor of the first ten Hungarian cities leading overnight stays in Hungary said that they supported new hotel investments, as far as they provided the basic infrastructure for the "greenfield" projects and the administration deadlines, where the local government was competent, would be handled flexibly and, if it was necessary, they could extend them several times too. Currently, it is not typical any more that local governments try to attract investors to their grounds with very much reduced prices; everybody wants to sell the grounds at the highest possible price.

Two opinions were typical in connection with competitiveness of the Hungarian hotel industry.

Firstly, there is no problem with the quality and the personnel, the hotels have been even better and more competitive since the renewals, the continuous service extension investments and the introduction of the Hotelstars Union system. More than sixty per cent of hotels had become controlled and qualified hotels in Hungary by the year 2015. One can rarely find 1- and 2-star hotels in Budapest and in the country, in the last ten years, the investors mainly built 4- star hotels (HCSO).

The subjective assessments on the hotel review sites also show that the hotels are even better qualified; one can experience extreme complaints for the services only very rarely.

Internationally, we heard rather negative and pessimistic opinions. Many of respondents emphasized that among the capitals that are included in the European hotel comparisons, Budapest is listed almost last in respect of the hotel industry indexes. Vienna and Prague, which are the main competitors from the point of view of tourism, overtake Budapest in every respect. It is necessary to point out that the problem is not with the quality of hotels, since Budapest is welcoming the guests with a range of high quality hotels as a whole. In connection with Prague, one has to mark that just over twenty years ago, at the time of the political transformation, the Hungarian capital had already surpassed the Czechoslovak capital in respect of the tourism possibilities and the exact indexes. The reasons have already been analysed by many people and they revealed that the roots point far beyond the frames of the hotel industry but even those of tourism as well. A foreign researcher's study about the tourism of Eastern Europe joins this idea, Hall, R.D. (1993), which included the 1980s and 1990s and some years after the political transformation, at that time he still considered Hungary to be the leading tourism destination of the region, which was proved objectively by the statistics of that time too. From the results of the research, the empiric hotel research (SPSS) could objectively show the most important tourism destinations on the basis of quantitative data and also that development and competitiveness of particular destinations are in close connection with development of the hotel industry in the region. The preceding research of other authors (Aubert, 2007), (Fehér \& Kóródi 2008) also arrived at the same result as far as the destinations are concerned. However, they did not study the issue from the point of view of the hotel industry though they also emphasized the importance of accommodations. However, the results of the structured interviews give reason for debates on many issues, as the experts also drafted different opinions in respect of development and competitiveness of the tourism destinations in Hungary. 


\section{CONCLUSION}

Tourism and within this the hotel industry is very concentrated in Hungary. It is focussed on a relatively few priority tourism destinations, where they had a developed and competitive hotel industry in turn. In addition, using the morals of competitiveness models of the tourism destinations, we can find a possible solution to numerous questions in detail, by assessment of a specific destination or by comparison of several destinations, what and how one would have to develop for the sake of a successful destination.

Primary research indicated that tourism is the most important branch in the micro regions that are ranked in the first group. Moreover, it is number one regarding employment providers for the local population and enterprises too.

These are, in general, the most important locations of the medical tourism (Hévíz, Hajdúszoboszló, Bük, and Zalakaros), where the number of permanent residents is relatively low and accordingly, the number of overnight stays, the intensity of tourism is high and other branches of economy are less significant. In case of majority of the settlements at Lake Balaton, tourism is the most important branch too, but the main season depending on the weather is very short for majority of inhabitants to actually earn their living from tourism alone in the whole year and in the long run.

The level of development and competitiveness of tourism in tourism destinations in Hungary is in close connection with the level of development of the hotel industry, because the main part of the hotel industry is settled next to the tourism attractions, whilst there are no hotels in the micro regions at all where there is a lack of significant attractions, which makes out a quarter of the territory of the country.

The structured interviews confirmed the results of the quantitative analysis and they also revealed professional correlations that can be hardly described and assessed with figures.

Concerning quality, the Hungarian hotel industry is generally competitive, although by international comparison, its performance indicators are fairly less favourable versus highly developed global destinations, for example famous capitals and holiday resorts.

The limit of the investigation was that it mainly studied development and competitiveness of the hotel industry in the tourism destinations; however, it did not study other features of the regions. The results of the research are valid in Hungary because the most successful and competitive tourism destinations are the ones where one can find a developed and active hotel industry and guests can stay in good-quality hotels for long stays. The study was not dealing with the competitive situation among hotels, categories of hotels and hotel types or with their relationships because it was not the target. However, a further research can certainly study these factors too. The research did not concentrate on the study of guest satisfaction levels in hotels and their impact on competitiveness either. This would be dealt with in a future study using primary research with questionnaires. 


\section{References}

1. Aubert A. et al. (Ed.) (2007). A kistérségi turizmuskutatás és tervezés módszerei, eredményei. (Methods of tourism research and planning in mincro-regions) Pécsi Tudományegyetem, Természettudományi Kar, Földrajzi Intézet

2. Blanke, J., \& Chiesa, T. (2009). The Travel and Tourism Competitiveness 2009.

3. Buhalis, D. (2000). Marketing the competitive destination of the future. Tourism Management 21. 97-116. http://dx.doi.org/10.1016/S0261-5177(99)00095-3

4. Butler, R. W. (1980). The concept of a tourist area cycle of evolution: implications for management of resources. Canadian Geographer, 14. (pp. 5-12) DOI http://onlinelibrary.wiley. com/doi/10.1111/j.1541-0064.1980.tb00970.x

5. Clarke, A. (Ed.) (2010). Constructing Central Europe Tourism Competitiveness. Veszprém: Pannon Egyetem, Gazdaságtudományi Kar

6. Dwyer, L., Forsyth, P., \& Rao, P. (2000). The price competitiveness of travel and tourism: A comparison of 19 destinations. Tourism Management, 21. http://dx.doi.org/10.1016/S02615177(99)00081-3

7. Dwyer, L., \& Kim, C. (2004). Destination competitiveness: Determinants and indicators. Current Issues in tourism, 5. DOI http://dx.doi.org/10.1080/13683500308667962

8. Fehér, I., \& Kóródi, M. (2008). A vidéki turizmus fejlesztése. (Tourism development in the countyside) Budapest: Szaktudás Kiadó Ház

9. Ferner, F. K. (1994). Idegenforgalmi marketing. (Tourism marketing) Budapest: Műszaki Könyvkiadó

10. Géher, Z. (2000). Key Performance Indicators. Budapest: KIT Képzőművészeti Kiadó

11. Gyurácz-Németh, P., Kovács, Z., \& Uden, L. (2010). Possible innovations in the management of hotels. In Clarke, A. (Ed.) Constructing Central Europe Tourism Competitiveness. 2010 (pp. 347-359) Veszprém: Pannon Egyetem Gazdaságtud. Kar

12. Hall, R.D. (1993). Tourism in Eastern Europe. In Pompl, W. \& Lavery, P. (Eds.) Tourism in Europe. Structures and Developments. 1993 (pp. 341-358.) Wallingford: CAB International

13. HOTREC (2002). Szálloda és vendéglátóipar Európában. (Hotel and Hospitality Industry in Europe) Budapest: KIT Kft.

14. HCSO (Hungarian Central Statistical Office) KSH Economic, Tourism, Social statistics. (data collection, 2007-2015) www.ksh.hu

15. Jancsik, (2011). A turisztikai terek életciklusát mérő indikátorok. (Indicators of Tourism Area Life Cycle) Turisztikai kutatások módszertana. 6. Digitális tananyag, Pécsi

Tudományegyetem (www.eturizmus.pte.hu)

16. Jurigová, Z. \& Lencsésová, Z. (2015). Monitoring System of Sustainable Development in Cultural and Mountain Tourism Destinations, Journal of Competitiveness Vol. 7, Issue 1, pp. 35 - 52, DOI: $10.7441 /$ joc. 2015.01 .03 
17. Jurigová, Z., Tučková, Z., \& Kuncová, M. (2016). Economic sustainability as a future phenomenon: moving towards a sustainable hotel industry, Journal of Security and Sustainability Issues 6 (1): pp. 103-112. DOI: http://dx.doi.org/10.9770/jssi.2016.6.1(7)

18. Kovács, P. (2004). Turizmusmarketing elméletben és gyakorlatban. (Tourism marketing in theory and practice) Székesfehérvár: Kodolányi János Főiskola

19. Kozma, B. (2006). Turizmus marketing. (Tourism marketing) Budapest: Budapesti Gazdasági Főiskola

20. Laužikas, M., Tindale, H., Bilota, A., \& Bielousovaite, D. (2015). Contributions of sustainable start-up ecosystem to dynamics of start-up companies: the case of Lithuania, Entrepreneurship and Sustainability Issues 3(1): pp. 8-24. DOI http://dx.doi.org/10.9770/ jesi.2015.3.1(1)

21. Lengyel M. (2004). A turizmus általános elmélete (Theory of tourism) Budapest: Heller Farkas Főiskola, Kereskedelmi és Idegenforgalmi Továbbképző

22. Lengyel M. (Ed.) (2008). TDM működési kézikönyv. (Tourism Destination Management Practical Handbook) Budapest: Heller Farkas Főiskola

23. Olaniyi, E. O. \& Reidolf, M. (2015). Organisational innovation strategies in the context of smart specialization, Journal of Security and Sustainability Issues 5(2): pp. 213-227. DOI http:// dx.doi.org/10.9770/jssi.2015.5.2(7)

24. Piskóti, I. (2012). Régió- és településmarketing. (Region and settlement marketing). Budapest: Akadémiai Kiadó

25. Poon, A. (1993).Tourism, Technology and Competitive Strategies. Wallingford: CAB International

26. Porter, M. E. (1980). The Competitive Strategy: Techniques for Analysing Industries and Competitors. New York: Free Press

27. Porter, M. E. (1990). The Competitive Advantage of Nations. London: MacMillan

28. Priszinger, K., \& Clarke, A. (2010). Competitiveness as a Risk Factor in Hungarian Wellness Hotel Developments. In Clarke, Al. (Ed.) Constructing Central Europe Tourism Competitiveness. 2010 (pp. 323-346) Veszprém: Pannon Egyetem

29. Puczkó, L. \& Rátz, T. (2000). Az attrakciótól az élményig. (Attractions to adventure) Budapest: Geomédia Kiadó

30. Ritchie, J. R. B., \& Crouch I. G. (2003); (2005). The Competitive Destination: A Sustainable Tourism Perspective. Wallingford: CABI Publishing. DOI 10.1079/9780851996646.0000

31. Shaw, G., \& Williams, M. A. (1994). Critical Issues in Tourism. Oxford: Blackwell Publishers

32. Tsai, H., Song, H. \& Wong, K.F. (2009). Tourism and Hotel Competitiveness Research. Journal of Travel \& Tourism Marketing. 26:5-6, 522-542. DOI http://dx.doi.org/10.1080/10548 400903163079

33. Tvaronavičienè, M., Razminienè, K., \& Piccinetti, L. (2015). Cluster efficiency study through benchmarking, Entrepreneurship and Sustainability Issues 3(2): pp. 120-128. DOI http://dx.doi.org/10.9770/jesi.2015.3.2(0)

34. Vanhove, N. (2011). The Economics of Tourism Destinations. London: Elsevier 
35. Vaško, M. \& Abrhám, J. (2015). Issues of secure and sustainable e-tourism: case of the Czech Republic, Journal of Security and Sustainability Issues 5(2): pp. 137-148. DOI http://dx.doi. org/10.9770/jssi.2015.5.2 (1)

36. World Economic Forum (2015). The Travel and Tourism Competitiveness Report. Geneva (www. weforum.org/ttcr.)

37. World Economic Forum (2013). The Travel and Tourism Competitiveness Report. Geneva (www. weforum.org/ttcr).

\section{Contact Information}

Attila Albert-Tóth, Assistant Professor

Széchenyi István University

Kautz. Gyula Economics Faculty

Tourism Department

9026 Györ, Eg yetem tér 1. Hungary

E-mail:albert.toth.attila@sze.hu 